\title{
The Good, the Bad and the Ugly: the representations of $O$ Estado de São Paulo newspaper about the three main presidential candidates in the 1989 elections $^{I}$
}

Thaíze Ferreira da Luz*

\begin{abstract}
This article proposes to analyze of the representation of political figures in the print media. From the point of view of representations, newspapers are able to provide information not only about society but also about the constitution of the social. The objective of this paper is to verify how the construction of the image of the three main presidential candidates of 1989 , Fernando Collor de Mello, Leonel Brizola and Luiz Inácio Lula da Silva, was made by the newspaper $O$ Estado de São Paulo and how these representations elaborate a symbolic construction of these candidates. For such, it was observed the use of the images in the pages of $O$ Estado de São Paulo and the discursive construction of the periodical, in the same edition.
\end{abstract}

Keywords: Political representation; Fernando Collor de Mello, Leonel Brizola e Luiz Inácio Lula da Silva; 1989 elections.

Representations in the media: a case study about the figure of the politician

Political History, after a few decades of discredit, in the last 30 years has drawn the attention of historians. Many works are produced based on this theme, so it is not appropriate to make a retrospective on this field of history, as we believe that the growing academic production is enough to justify our interest in the subject.

We can say that the studies of the History of the Present Time go back to the very renewal of the studies of Political History. According to Reinaldo Lohn, "more than ever, a history committed and challenged by the present is facing questions that involve the interaction between historical narrative and the political field" (LOHN, 2019, p.II)

Thinking about this perspective of the renewal of Political History studies based on the History of the Present Time, we find that the media, especially newspapers, end up being a field of intellectual construction and a space of dispute, where they elaborate

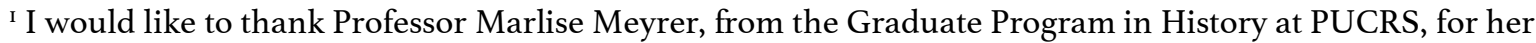
valuable contribution to this work.

" PhD student in History at PUCRS/CAPES, Master in Geography (FURG) and Degree in History (FURG) e-mail: thaizefl@gmail.com; This work was carried out with the support of the Coordination for the Improvement of Higher Education Personnel - Brazil (CAPES) - Financing Code oor; This study was financed in part by the Coordination for the Improvement of Higher Education Personnel - Brazil (CAPES) - Finance Code ooI.
} 


\section{C) HitistóñICA}

"forms of translation referred to both to the horizons of understanding and to the habitus, as discourses and practices that act as references for social interaction, the definition of objectives and desires and the fixation of meaning". (LOHN, 2019, p. 18).

We understand that in order to understand the functioning of regimes and institutions, it is essential to study the political field and its social and cultural implications, as part of the process of consolidating democracies. Knowing the elements that form and bound the political ${ }^{2}$ culture of a society is a fundamental task to understand how its political institutions work and the factors that legitimize the political agents that control that society.

In this sense, we will work with the definition of "political" of the French School, defended by Pierre Rosanvallon: "The political is not an instance or a domain among others of reality, but the place where the social and its representation are articulated, the symbolic matrix where the collective experience takes root and is reflected at the same time" (ROSANVALLON, 1995, p. 30). And to understand this concept, it is necessary to use documentary sources considered until recently as "less important", such as the press, pamphlets, popular literature, lawsuits, etc.

We believe that newspapers constitute a universe formed and constructed through speeches and representations of the political world, capable of "informing" the reading public about politics with the aid of instruments and techniques peculiar to the journalistic medium that, in most cases, do not match the reality. According to Jodelet (200I, p. I7-I8), “The observation of social representations is natural on multiple occasions. They circulate in the speeches, are brought by words and conveyed in media messages and images, crystallized in behaviors and in material and spatial organizations".

In this way, newspapers become important study objects for the study of political representations through the analysis of their speeches. In them we can have a local explanation of the meaning of the political world and, being an important source of information, their influence on the public scene as opinion makers is undeniable.

From the point of view of representations, newspapers are able to provide information not only on society but also on the social constitution:

\footnotetext{
${ }^{2}$ On the concept of political culture, we will work with the following definition: "political values, attitudes and procedures are reinforced from the interaction between the behavior and the functioning of political institutions, something that implies both processes of learning how to use them and of political resocialization induced by experience, but both are based on the time and with the continuity of the processes that constitute the political systems" (MOISÉS, I995, p. 94)
} 


\section{C) GitistóróRICA}

Social representations are complex phenomena that are always activated and in action in social life. In its richness as a phenomenon, we discovered several elements (some sometimes studied in isolation): cognitive, ideological, normative information, beliefs, values, attitudes, opinions, images, etc. However, these elements are always organized under the appearance of knowledge that says something about the state of reality (JODELET, 200I, p. 2I).

The communication process is fundamental for us to understand social representations:

The processes that shape and transform social representations are intrinsically linked to communicative action and social practices in the public sphere: dialogue and language, rituals and productive processes, the arts and cultural patterns, in short, social mediations. Thus, the analysis of social representations must focus on those processes of communication and social life, which not only produce them but also give them a peculiar structure (JOVCHELOVITCH, 200o, p. 80)

The specific structure of the journalistic activity, allows a discursive analysis capable of understanding how its performance and influence as a form of opinion is legitimated, capable of interfering in the public scene, being also an instrument of politicians and at the same time, a political agent.

\section{Theoretical and methodological aspects}

We propose to make a documentary analysis through the representation made by the newspaper O Estado de São Paulo (OESP) of the three main candidates who ran for the I989 presidential election, using the September 5, I989 edition. This is not a broad analysis on the topic, but an analysis of imagery and discursive elements present in a single edition of the aforementioned newspaper. In our research, we worked with the present periodical between the years 1987 to I992. For this work, our choice was because it was an edition that showed the agenda of the three candidates on the same day, that is, it was possible to

\footnotetext{
3 We understand here that the term "public sphere" used by the author is not the most appropriate, considering that in the case of the formation of opinion and social representation made by the mass media, it is not possible to apply the Habermasian concept of public sphere. In the case of this type of communication vehicle, we consider the term "public scene", developed by Gabriel Tarde (TARDE, Gabriel. A opinião e as massas. São Paulo: Martins Fontes, 1992.)
} 


\section{C) HițTon T́RICA}

verify in the same edition, the type of message passed on the electoral agenda of each of the main candidates for the presidency of Brazil in 1989, as well as the way in which the imaginary construction of each one took place in the pages of OESP. In three reports, showing each of the candidates, ten days before the start of the free electoral time for radio and television, where it was possible to identify a different treatment used by the periodical in the presentation of the three candidates, whose analysis we will do in the next topic of this article.

In this sense, we will work here with the concept of representation by Roger Chartier, that all representation, "represents something". According to the same author:

Such representations are not simple images, true or misleading, of a reality that was external to them. They have their own energy that convinces that the world, or the past, is really what they say it is. Produced in their differences by the distances that fracture societies, representations, in turn, produce and reproduce them. Therefore, conducting the history of written culture, making it the cornerstone of the history of representations, is to link the power of written texts that make them read, or listen, with the socially differentiated mental categories that they impose and are the matrices of classifications and judgments. (CHARTIER, 20IO, p. 67).

We reached this conclusion by looking at the discursive and imagery elements presented by OESP, where the choice of images, the position of the news on the newspaper page and the text used, show the intention of its speaker, clearly seeking to form the opinion of the recipient of that information. Although, due to the heterogeneity of the reading public, we obviously have no way of specifying the scope of the discourse used.

Still on OESP, here is a brief presentation of the analyzed journal. Founded on January 4, I875, still in Imperial4 Brazil, it was called "Província de São Paulo", having its name changed to $O$ Estado de São Paulo with the implantation of the Republic. Its founders were Américo Brasiliense de Almeida Melo and Manuel Ferraz de Campos Sales. In the year I885, Júlio César Ferreira de Mesquita joined the newsroom, who soon became

\footnotetext{
4 For this information we also use the collection of the journal itself, available at https://acervo.estadao.com.br/historia-do-grupo/decada_1870.shtm, accessed in June 2018 and the CPDOC FGV entry file, available at https:/cpdoc.fgv.br/sites/default/files/verbetes/primeirarepublica/ESTADO\%20DE\%20S.\%20PAULO,\%20O.pdf, accessed June 2018.
} 


\title{
C) Hitistó RICA
}

director. To this day, the newspaper's management remains in the Mesquita family. Its orientation maintained the tradition of placing in his editorials a stance that combines conservatism and liberal policies. In the I980s, it took on a neoliberal stance, due to the current international context, with the end of the Cold War and the beginning of globalization (SODRÉ, 1999, p. 226-227).

The analysis of the discourse and its discursive formations is a way of identifying and understanding cultural, symbolic and value elements that form a universe of meanings, capable of showing how social groups understand the world that they are inserted in.

\begin{abstract}
The development of mass media means that the direct encounter for the establishment of conversation and discussion, as well as the exchange of information, is increasingly irrelevant. The mediation of the mass media produces a shift in public experience and, at the same time, shapes the possible knowledge that this experience develops about itself. By becoming the most widespread form of social communication in contemporary societies, the mass media inform and shape the public sphere. They do so in such a way that information and representations about the public sphere replace any and all experiences in the public sphere (JOVCHELOVITCH, 200o, p. 86). ${ }^{5}$
\end{abstract}

If in the past, political debate was held in coffees shop and lounges, nowadays with an increasingly individualistic society, the media end up bringing together "virtual" groups of people who share similar ideas, even though they are not present in the same physical space (TARDE, 1992, p. 29). The mass media end up occupying the public scene.

In turn, the use of image in the journalistic medium has as its starting point the search for the objectivity of the profession and a way of "proving" that a certain fact happened. However, like words, an image does not always accurately translate the reality it is intended to represent. This is because:

The transmission of elements of the past to the historian by the photographic message, however, should not be limited to the scope of pure and simple communication. It is precisely the search for the logic

\footnotetext{
${ }^{5}$ Same earlier note on public sphere.
} 


\section{G) HitșTón}

of such elements in a given time and space that makes them acquire a meaning that can both inform material aspects [...] as well as to reveal an image/monument: what, in the past, society wanted to perpetuate itself for the future. [...] In this sense, the production of the photographic message is linked to the control of the technical means of cultural production which, until around the I950s, was still an almost exclusive privilege of sectors of the ruling class (MAUAD; CARDOSO, 1997, p. 406407).

Thus, our interest in this work is to make a discursive and imagery interpretation of the selected news, in order to problematize the way OESP built the image of each of the three main candidates for the 1989 presidential election, since the choice of the type of photo presented (clothing worn by candidates, body expression, being was close or full body) to the words used in describing the news and the relationships made with the candidates' stance and their election campaigns.

In this case study, we made an analogy to the famous film The good, the bad and the $u g l y$, in which three gunmen come together in a race to find a hidden treasure. The film's proposal is that the three should help each other, considering that each one has the partial location of the treasure. However, the desire to keep the prize is greater, so that each of them tries all the time to find the reward alone.

In the 1989 election, the "treasure" is the victory in the election. In the case of an electoral dispute, the winning candidate will be the one who can best sell his ideas and pass on a better image to the electorate. In this perspective, analyzing the way in which OESP presented the three main candidates in the 1989 electoral race, we can perceive, by the selection of images and texts to support the reports and news made for each of the candidates, a different intention. From this, we identified the following characteristics, from the perspective of OESP on the leaders of the electoral polls of 1989.

OESP, as a representative of the "interests of the people", throughout the 1989 electoral process, tried to pass an image of impartiality and impartiality, the most effective way to legitimize his speech as an opinion maker on the public scene. However, although it presented space for all candidates in the electoral election, for this analysis, we chose to speak only of the three candidates with the most intentions to vote. It is possible to identify that the way he used his space, words and images, is able to show that two of the three 


\section{G) Hiticátórica}

projects presented to occupy the chair of the presidency of Brazil, clearly did not please the liberal project of the periodical.

Fernando Collor de Mello: The Good
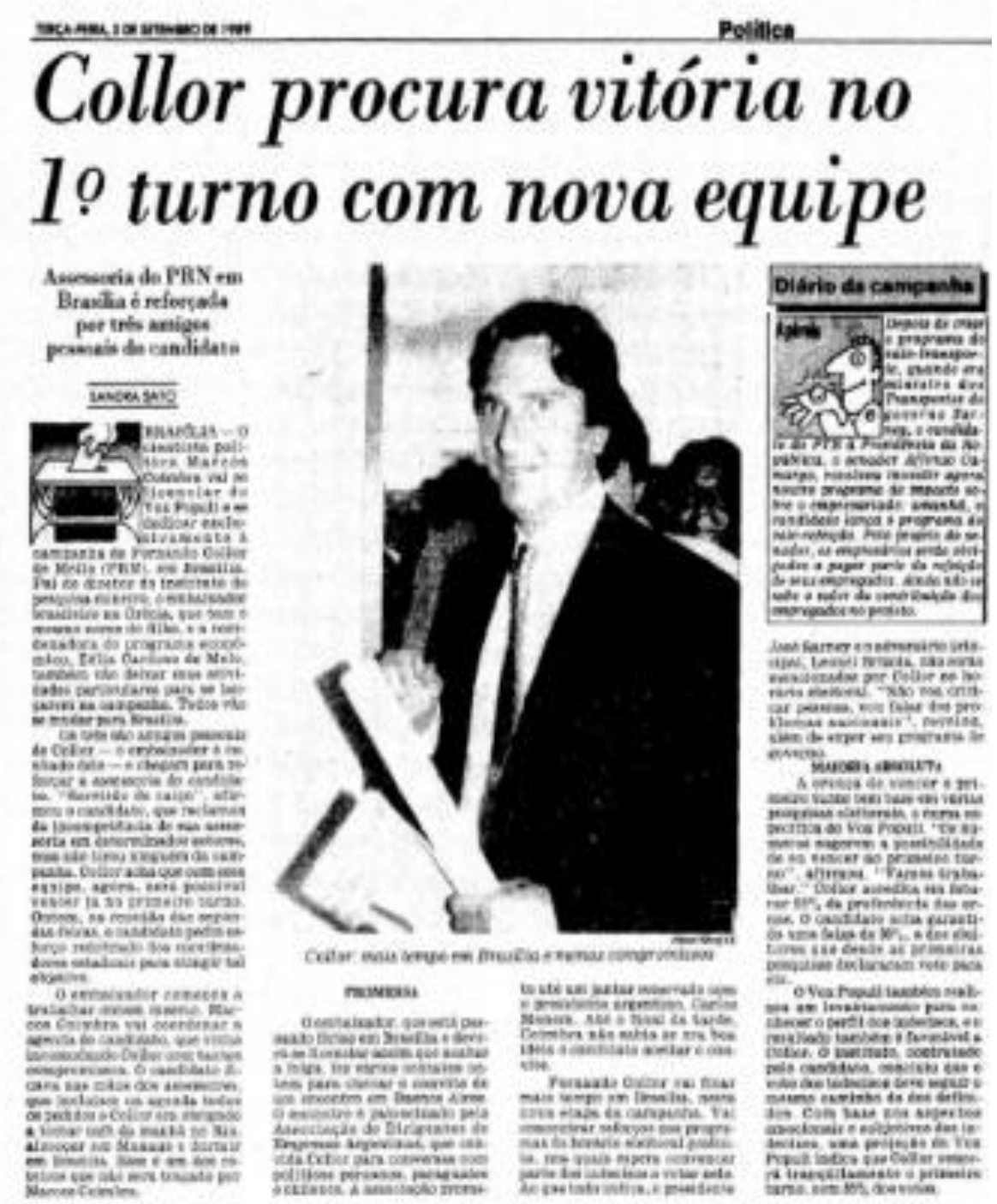

FIGURE oI: OESP, 09/05/1989 p. 5 - Politics

The report made with the advice of Fernando Collor de Mello, candidate for the National Republican Party (PRN) published by OESP on 09/05/1989, appeared on page 5 of its policy section. The text occupies the entire upper left corner. To the most inattentive reader, this simple information may pass unnoticed, however, our experience in studies with the press as an object, teaches us that this is the reading preference of newspaper consumers. Thus, the layout presented by the journal already highlights the figure of Collor. 


\section{C) GitistóróRICA}

The textual elements occupy two large columns on the left and right and two small columns below Collor's photograph. The title - "Collor seeks victory in the first round with a new team" - is written in bold, in medium font. Below, we have the supporting text "PRN's advisory in Brasilia is reinforced by three personal friends of the candidate" - is written in small text, also in bold.

The content of the report highlights the arrival of three personal friends of Fernando Collor de Mello to his advisory team: Zélia Cardoso; Marcos Coimbra and Marcos Coimbra Filho. The first responsible for the economy and the last two for the press office. Everyone will move to Brasilia, as candidate Collor believes in victory in the first round and wants to focus his campaign on winning the votes of undecided voters.

Marcos Coimbra will graduate from Instituto Vox Populi, the body responsible for conducting opinion polls and dedicating himself exclusively to Collor's electoral campaign. The certainty of victory in the first round comes from there. In surveys carried out by the institute at the request of Collor, a profile of undecided voters was drawn up and on the eve of the start of the free radio and TV election hours, Collor will spend more time in Brasília, devoting himself to the production of programs whose purpose is to conquer of these specific voters. At the end of the report, the candidate stresses that in his program he does not intend to attack President Sarney or his political opponents, he is only focused on showing the solution to Brazilian problems and winning over the undecided electorate.

The imagery content shows Collor in a suit and tie, with a serene and confident image. In his left hand, he takes notes and government plans, and in the other, a clenched fist, as a symbol of struggle and determination.

From the combination of textual and iconographic elements, we have a representative image of Collor, made by OESP, as a worker, focused, confident that the result of his work will be victory and that his campaign does not intend to reach the image of the other candidates or the current one head of government. Definitely, THE GOOD candidate! 
Leonel Brizola: The Bad

\section{brizola tenta mudar a imagem e conta piadas}

Drpais de umu armana de proverias easilidate silosa hue haser do idernaire Malel

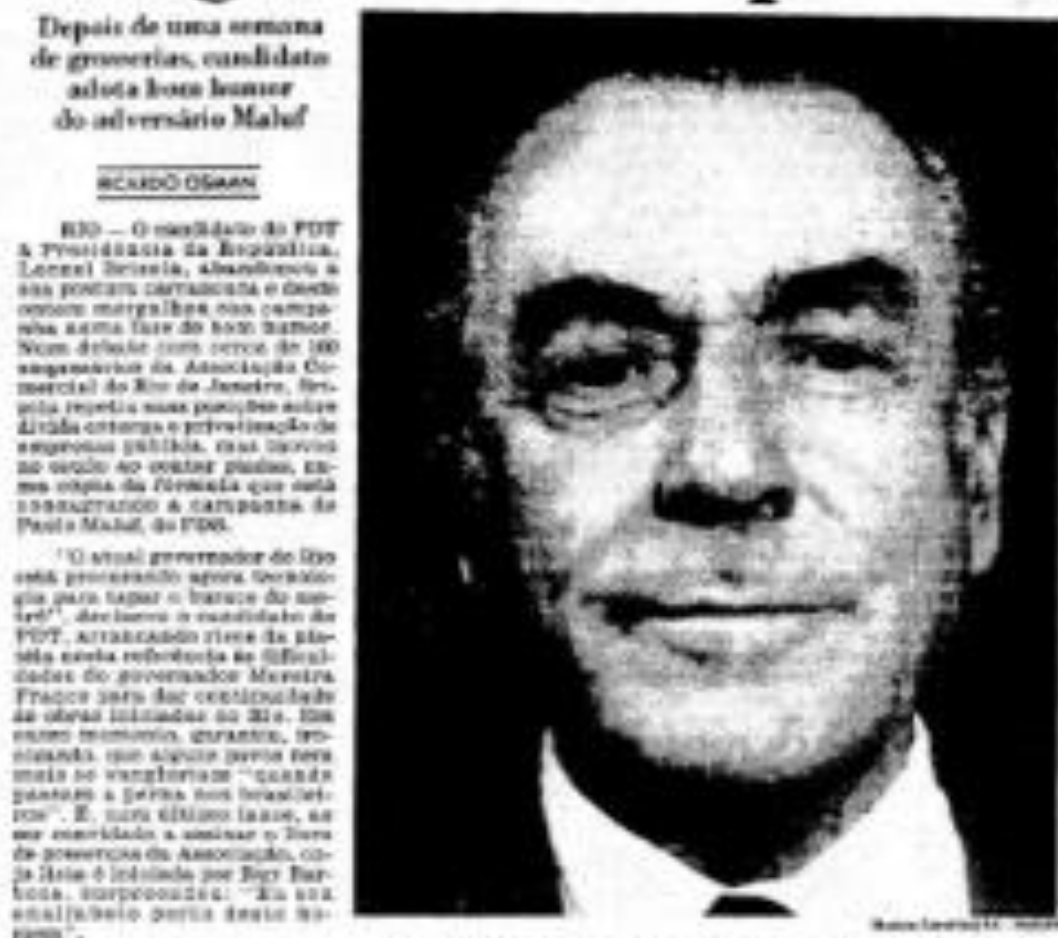

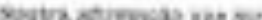

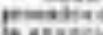

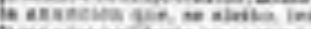

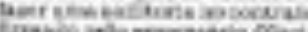

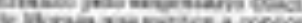

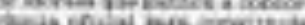

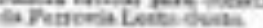

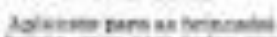

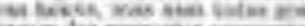

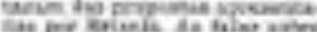

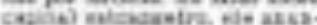

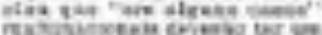

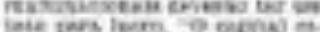
gie pars leom o oconw

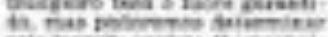

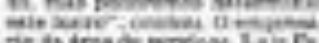

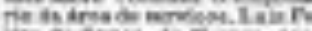

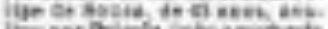

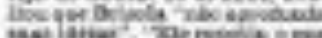

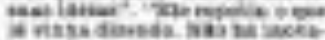

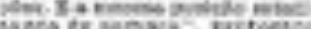

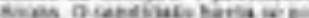

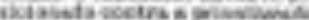

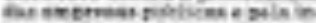

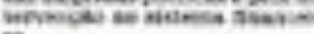

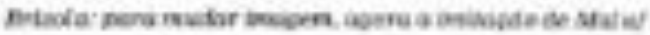

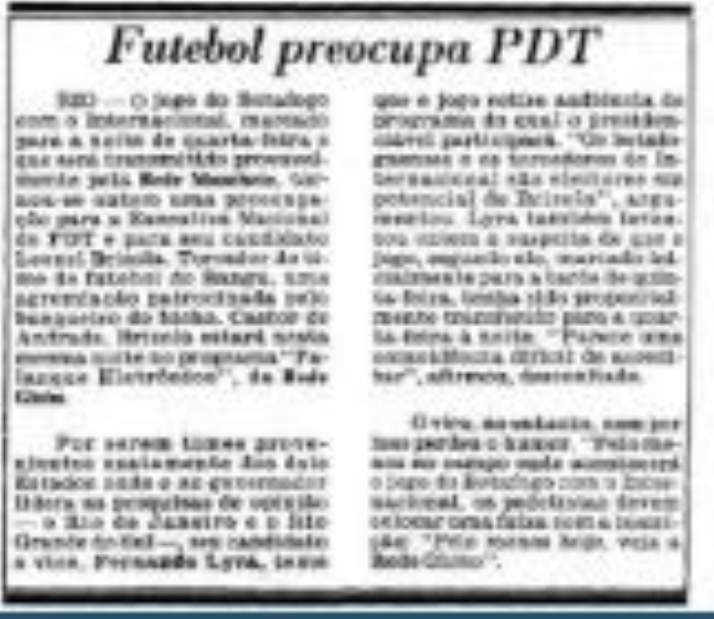

FIGURE 02: OESP 09/05/1989 p.4

The report made with Leonel Brizola, was published by OESP on 09/05/1989, on page 4 of its policy section. The text occupies the upper right corner. This position on the newspaper page already shows that the candidate of the Democratic Labor Party (PDT) does not deserve so much credit for the periodical. The textual elements occupy a large column. The title - "Brizola tries to change the image and tells jokes" - is in bold and medium 


\section{G) CitsistórICA}

font. Below, we have the support text in small font: "After a week of rudeness, the candidate adopts good humor from opponent Maluf".

In addition to the main story text, we also have two columns below Brizola's photograph, on a second subject. In this, the candidate's concern is to have his audience in a political program disturbed by the broadcast of a football match, at the same time, by another broadcaster.

The main story text highlights a change in attitude adopted by Leonel Brizola. "The candidate Leonel Brizola, abandoned his scowl and since yesterday, he plunged his campaign into a phase of good humor". This report was produced the day before its publication on the occasion of Brizola's meeting with businessmen at a dinner at the Commercial Association of Rio de Janeiro.

At the meeting, Brizola repeated his positions on the main economic issues that concern entrepreneurs in that state: foreign debt; privatization of public companies and government interference in economic matters. Despite "innovating" by telling jokes, using a copy of the formula established by Maluf in his electoral campaign, for OESP, Brizola did not convince the businessmen present at the meeting, being presented by him, almost in a caricature.

Even including this new way of addressing people, the journal is emphatic in highlighting that Brizola did not innovate in relation to its main positions. You don't want to privatize public companies; it will limit the investment of foreign capital in the country and intends to adopt an interventionist model in the financial system. Thus, the entrepreneurs ended up defining Brizola as a candidate who "does not deepen his ideas. It does not innovate and does not renew its positions, considered to be staticizers".

The imagery content shows a close-up of Brizola's face, where we can see that he is wearing a dark suit and tie. It is not possible to identify the location where the photo was taken. His image shows the attempt to smile, however, "without showing his teeth", that is, for OESP, Brizola remains the old "warlord", who tries to use the artifices of another candidate, however, without convincing the electorate and entrepreneurs. . It is the BAD example to be followed. 


\section{PT dá ultimato a dissidentes}

Cowa 0perimia e

Gonwretaria diverzum de parlíle tèn es dias contadse

$$
\text { Puterainet }
$$

A Corrantos bertivis

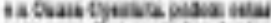

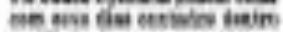

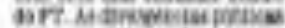

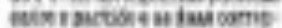
iet wis slaan ta ingense is

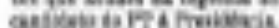

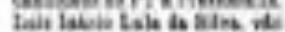

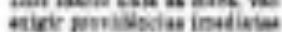

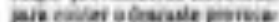

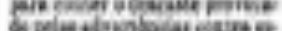

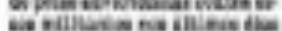
conator

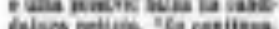

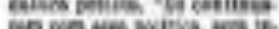

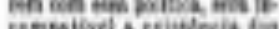

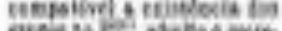

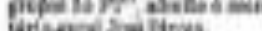

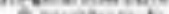

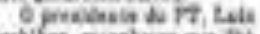

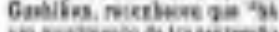

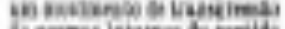
4 axnat latara de artas

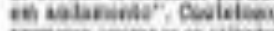
Donme werv on blian: prias os aim inlatei on

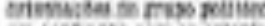

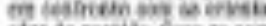

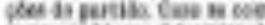

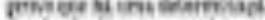

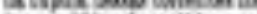

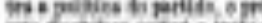
mo osaver otil a int

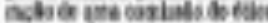
paradocaterses.

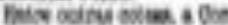

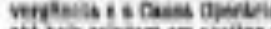

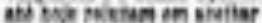

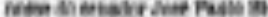

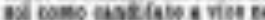

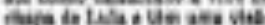

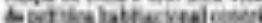

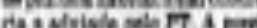

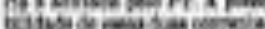

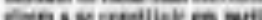

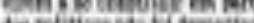

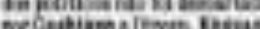

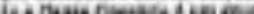

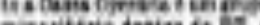

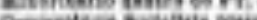
Compde etruldis

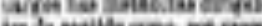

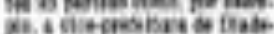

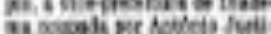

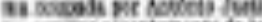

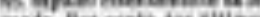

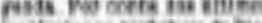

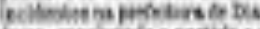

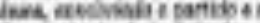

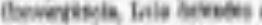

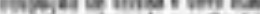

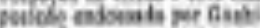

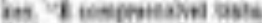

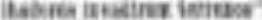
atrine

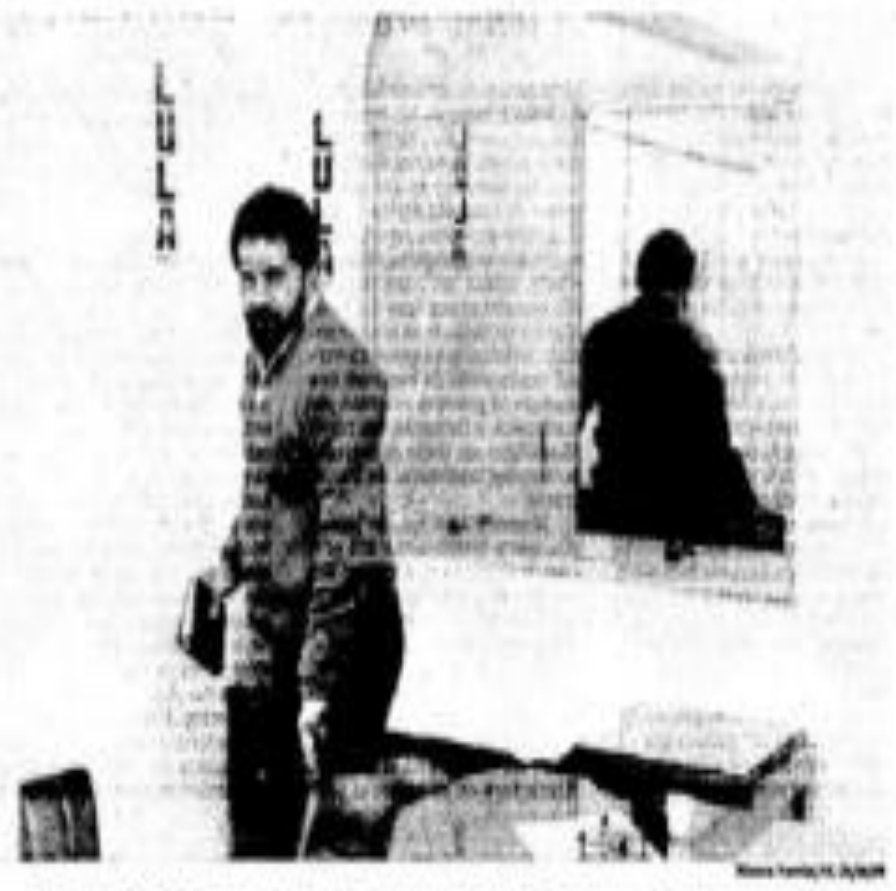

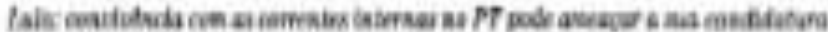

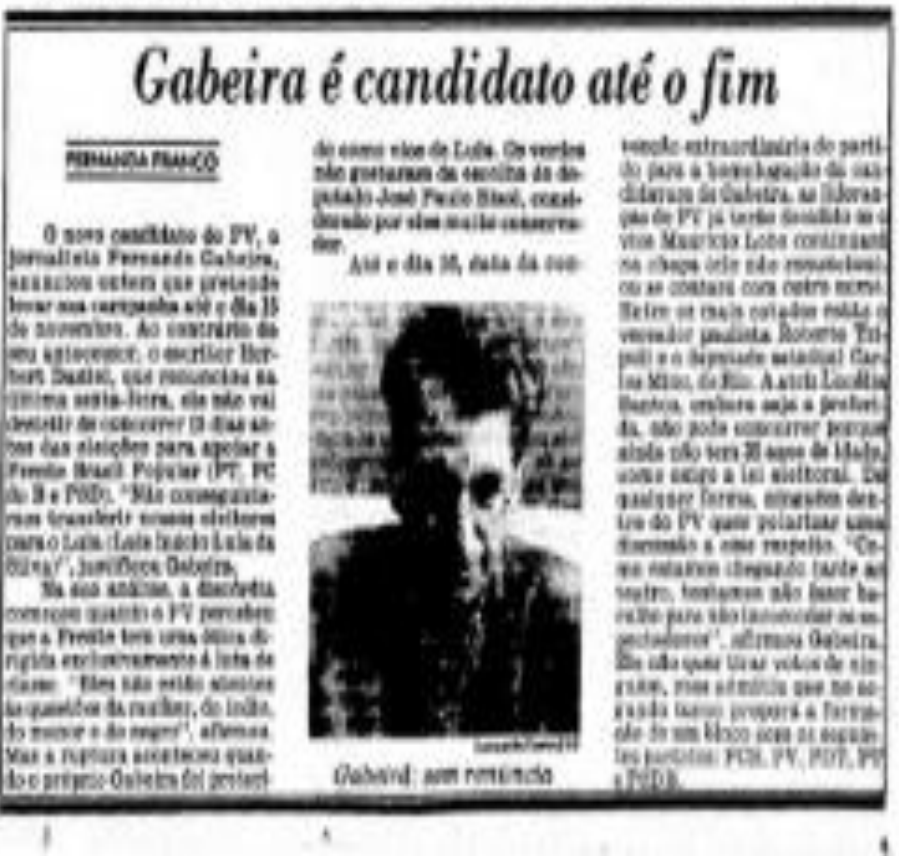

FIGURE 03: OESP, 09/05/1989 p. 4

The report made with Luiz Inácio Lula da Silva, from the Workers' Party (PT) was published by OESP on 09/05/1989, on page 4 of its policy section. The text occupies the 


\section{G) Gitsó TórICA}

bottom right corner. This position on the newspaper page is one of the least privileged from the point of view of journalistic strategy, used to publish subjects of lesser relevance, demonstrating that the newspaper is not very interested in highlighting Lula's campaign.

The textual elements occupy a large column. The title - "PT gives dissidents an ultimatum" - is in bold and medium font. Below, we have the support text in small font: "The Socialist Convergence and the Workers' Cause may have their days numbered within the PT".

The report made with the candidate shows Lula's "concern", as evidenced by OESP, in losing allies in a decisive stage of his election campaign. The militants of Socialist Convergence and the Workers Cause are unhappy with the stance taken by the leadership of the Workers' Party. This is causing friction and threats for these two currents to stop supporting him, very close to the beginning of free election propaganda.

For OESP, the central point of this dissatisfaction, revolves around the choice of the candidate for the vice-presidency of the PT, senator José Paulo Bisol. The impasse is because the militants of the Workers' Party have a different stance than Bisol's regarding the vision of housing policy.

In the report, Lula says that if necessary, an investigation will be opened to solve the problems that threaten the loss of support for the party at a crucial moment in his electoral campaign.

Lula's image shows the candidate on the electoral committee of the Workers' Party, with pants and shirt, holding a diary in one hand, without a suit and tie like the other two candidates presented by the newspaper. Another difference is that while Collor and Brizola were presented only showing the upper back, Lula's image is full-length, in an unreliable and sloppy posture. His face looks worried and uncomfortable with the situation he needs to resolve at this stage of his campaign, in the decisive race to remain in contention in the second round of the elections.

Passing a frown of Lula, OESP represents the candidate as someone who has no security about the future of the party itself, let alone, about the future of a country. Unable to convince his allies of militancy, Lula is the UGLY example, which should not be followed, much less, should the electorate deposit their vote of confidence in this candidate. 


\section{(C) GitșTórica}

\section{Conclusion}

In this article, we seek to make an analysis, even if introductory and punctual, of the representation made by the media, especially the printed media, with the OESP newspaper in this documentary study, raising some methodological aspects to understand the choice of certain discursive and imaginary elements by the periodicals.

It was possible to realize that both linguistic and iconographic elements can be used in the service of the media to elaborate a representation of political reality, even if this is not the "true reality".

The good, the bad and the ugly appear personified in the figures of the three main candidates for the 1989 presidential election, by Fernando Collor de Mello, Leonel Brizola and Luiz Inácio Lula da Silva. The country's economic policy in that context, along with the friction of politicians considered traditional and the persecution of populist and socialist models, made the press occupy a prominent place, acting significantly, bringing to its pages the disputes of the political arena.

The election of Fernando Collor de Mello to the presidency of Brazil in 1989 and later his fall in 1992, are milestones of the country's political history. Marked by the return of political and civil liberties, this period brings new elements to the political arena, such as, for example, greater participation and popular demand in public affairs, also resulting from the Citizen Constitution of 1988; and the resumption and need on the part of the press, to be a more participative agent in this process, that is, the institutional role of the press in issues related to Brazilian politics. However, the economic scenario at the time of his inauguration was the worst possible: inflation reached the rate of $80 \%$. This was one of his government's greatest demands. Marked by failed economic plans, scandals and corruption, Collor, in addition to being the youngest elected president, also became the first to be impeached.

The newspaper O Estado de São Paulo is a representative of the great Brazilian press that, from the I950s, gradually took on a business structure. His writing began to introduce new writing techniques, guaranteeing this vehicle a significant growth, especially between the years 1950 - 1970, enabling him the ability to become an important opinion maker ${ }^{6}$.

Using textual elements and editing resources, ranging from the choice of image, the candidate's best angle and face expression; clothes; gestures; even the position that the report occupies on the newspaper page, it is undeniable that the mass media, occupies

${ }^{6}$ According to Aquino (1999); Barbosa (2007); Ribeiro A. (2003) and Ribeiro L. (2004). 


\section{C) CitsistórICA}

an important and even worrying role in the public scene. Thus, we believe that the study of politics with the press as the object of research, provides us with interesting debates on the subject, in addition to a very rich field of analysis.

\section{References}

AQUINO, Maria Aparecida de. Censura, Imprensa, Estado Autoritário (1968-1978). Bauru: EDUSC, 1999.

CARDOSO, Ciro Flamarion. MAUAD, Ana Maria. História e Imagem: os exemplos da fotografia e do cinema. In; CARDOSO, Ciro Flamarion. VAINFAS, Ronaldo. Domínios da História. Rio de Janeiro: Editora Campos, 1997. Pp. 40I-4I8.

CHARAUDEAU, Patrick. Discurso das mídias. São Paulo: Editora Contexto, 2006. . Discurso Político. São Paulo: Editora Contexto, 2006.

. MAINGUENEAU, Dominique. Dicionário de Análise do Discurso. São Paulo:

Editora Contexto, 2004.

CARTIER, Roger. Escutar os mortos. In: Revista Estudos Avançados, vol. 24, n.69, São Paulo:20Io. Available at: Http://anpocs.com/index.php/estudos-avancados/usercategory/26-estudosavanccados/I47-estud-av-vol-24-no-69-sao-paulo-20Io/66I5-revistaestudos-avancados, accessed in November 2019.

FOUCAULT, Michel. A ordem do Discurso. São Paulo: Edições Loyola,2004.

JODELET, Denise. As representações sociais. Rio de Janeiro: EdUERJ, 200I. 420p.

JOVCHELOVITCH, Sandra. Representações sociais e esfera pública: a construção simbólica dos espaços públicos no Brasil. Petrópolis: Vozes, 2000.

LOHN, Reinaldo Lindolfo. Reflexões sobre a História do Tempo Presente: uma História do vivido (p.II-26). In: REIS, Tiago Siqueira, et al. Organizadores. Coleção história do tempo presente: volume I, Boa Vista: Editora da UFRR, 2019. 250p.

MOISÉS, J. A. Os brasileiros e a democracia. São Paulo: Ática, I995.

RIBEIRO, Ana Paula Goulart. Jornalismo, literatura e política: a modernização da imprensa carioca nos anos I950. In: Estudos Históricos, Rio de Janeiro, n. ${ }^{3}$ 3I, 2003, p. I47I6o. 


\section{C) CitsistórICA}

RIBEIRO, Lavínia Madeira. Imprensa e Espaço Público. A institucionalização do jornalismo no Brasil. I080-I964. Rio de Janeiro: e-papers, 2004.

SODRÉ, Nelson Werneck. História da imprensa no Brasil. $4 .^{\mathrm{a}}$ edição, Rio de Janeiro: Editora Mauad, 1999. 502p.

TARDE, Gabriel. A opinião e as massas. São Paulo: Martins Fontes, I992.

Site:

O Estado de São Paulo - acervo: https://acervo.estadao.com.br/, accessed in June 2018.

CPDOC FGV - Verbetes: O Estado de São Paulo (jornal):

http://www.fgv.br/cpdoc/acervo/dicionarios/verbete-tematico/estado-de-sao-paulo-o, accessed in June 2018. 


\section{C) HitistóñICA}

\section{ANNEXES}

ANNEX I - Support text for figure oI - Fernando Collor de Mello

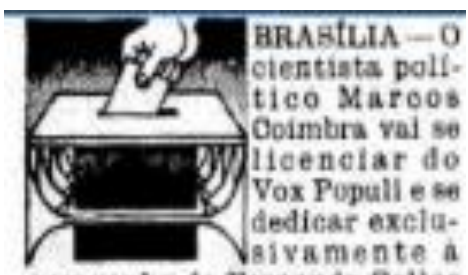

campanha de pernando Collor de Mello (PRN), em Brastilia. Paj do diretor do institato de pesyuisa mineiro, o embaixador brasileiro an Grecia, que tem 0 mesmo nome do fllho, $e$ a coordenadora ifo prosrama ecenomico, Zélia Cardoso de Melo. tambem vio deixar suas atividades particulares pars se lancarem na campanha. Todos vilo se mudar bara Brasitia.

Os tres sto amieros pessirais de Collor - o embaixador è cunhado dele - e cheiram para reforçar a aseessuria do candidato. "Bervitado de caleo"., afir. mots o candidato, que reclamou da incombutêncis de sus arecsgoria em determinados setorve. mas nso tirou ninguen da cam. panha. Collor acha que com essa equipe, agora, sera possfvel voncer já no primeiro turtio. Ontem, na reuniล๊o das eegandas-feiras, o candidabo pedin esforco redobrado dos coordenadores eatadaais pam atingir tal objetsvo.

$O$ embalxador comepou a trabalhat ontem mosmo. Mar. cos Coimbra val coordenar a acenda to candidato, que vinha. Incomodando Collor com tantos compromissos. 0 costididate ffeava nss milos dos assegsorts, que inclainm na agenda todos os podidos e Collor ora obrizado a tomar cafo da manha no Rio. almoçar em Mamals e dormir em Brasilia. Esce ê am cos no. teiros que nalo sera traçado por Marcos Coimura. 


\section{C) CitcoátórICA}

Collor: mats tempo em Brasilia e menos compromissos

\section{PItomessa}

0 embalkador, que esta pasBasdo ferias em Brasilia e deverâ se licegeiar assim que acabar a folga. fea virios contatos onLem para checar o convite de um encontro em Buenos Aires. 0 encontro 6 patroctaado pela Assoclaçao de Dirigentes de Empresas Argentinas, que cotivida Collor para cotversas com politicos peruanos, paraguajos e chilenos. A aasociacho prome- te ate um jantar reservado com 0 presidente argentino, Carfos Menem. Ate o final dis tarde. Coimbra aso asbia se era boa ideis o candidato aceitar o convite.

Yernasdo Collor val floar mais tempo em Brusilis, nesta novs etapa da campasha. Vat concevtrar esforcos bos prostamas do hordidto eleitoral gratul50. nos quais espera convencer parte doe indecisos a votar nele. Ao que talo indich, o prosidente
Jose Barney e o ndversario principal, Leonel Hrizola, nAo aertio mencionados por Collor no honario eleitoral. "Nato vou criticar pessoas, you falar dos problemas nacionals", revelou, alem de expor geu programa de governo.

\section{MAIORLA ABSOLLTA}

$A$ crenca de vencer o primelro turno tem base em vilfias pesquisas eleftorats, e vuma esDociflca do Vox Populi. "Os nu. moroe sugerem a posstbilidade de ea vender no primeiro turno", affrraou. "Vamos trabaThar." Collor acredita em faterar $55 \%$ da peeferencla das urnas, $O$ canitidato soha garantl. da uma faixa de $3 \sigma^{\prime}$. a dos eleitores que desde as primeiras peequfasa declararam voto para ele.

O Vox Populi tamberm reali. zoa am levantamento para coshecer o perfli dou tadecteos, 60 resultado tamberm é favoravel a Collor. 0 instituto, contratado pelo candidato, conclait que 0 voso dos indecisos deve seguir o mesmo caminbo do dos definidos. Com base nos anpecton emocionais e eubjetivos doe in đeciso日, uma projeço do Vox Popult indioa que Collor venoera tranquilamente o primeiro turno, com 55\% doe votos. 


\title{
C) HitistórRICA
}

ANNEX II - Supporting text figure 02 - Leonel Brizola

\author{
Depois de uma semana \\ de grosserias, candidato \\ adota bom humor \\ do adversário Maluf
}

\section{RICARDO OSMAN}

RIO - O candidato do PDT A Presidénela da Repúbllea. Leonel Brizola, abandonou a eus posturn carranouda $e$ desde ontem mereulhou sua campa. nha numa fase de bom humor. Num debate com cerca de 100 empreaditios da Aseoclacto Comercial do Rio de Janeiro, Brizola repetiu suas posiçoes sobre dfvida exterrsa e privatizachio te empresas pablica, mas fnovou no estilo an contar piadas, nama oopia da formula que esta consagrando a eampanhs de Paulo Maluf, do PDS.

"O ataal grovernador do Rio esta procarasdo agora tecnoloria para tapar o buraco to metro", declaron o candidato do PDT, arranoando risos da platesa nesta referencta is dificaldades do sovernador Morelra Fraboo para dar oontinuldade ds obras iniciadas no Rio. Rm outro momento, itarantiu, ironizando. que alruns povos nem mais se vangloriam "quando Dasasm a Derna nos brasiletros', E, num titimo lasce, ao ser convidado a absinar o livro de premenças da A ssociacto $\mathrm{cu}$ fa ilsta é inlefada por Ruy Barbosa surpreendeu: "Eu soa analfabeto perto deste ho. mem". 


\section{C) Hististórica}

Noutra afirmacto que sarpreesdeu os empreadrlos, Brizola anunotou que, ge oleito. irs faser uma auditoria no contrate Armado pelo empresirio Olacir de Moraes que ganhou a concorréncia ofieial para constraça da Perrovia Leste-Oeste.

Aplansos rara as brincadejras houve, mas sem todos gostaram das propostas apresonta. dall por Brizolat. Ao falar gobro capital estrangeiro, ele anua. clou que "em alguns casos" multinacionais deverho ter um teto para luero. "O capital es. trangeiro tera o lacro garantido, mas poderemos determinar eate luoro", eonvon. 0 empresi. rio da area de nervicoe, Luis Yelipe de Souza, de 45 anos, avaHou que Brizola "ndo aprofunda suas idelas". "Ble repetlu o que fit vinha direndo. Nao hd inoveob̂n. É a mesma posiclo estatizante de sempre", proteston Souta. 0 candidato havia se po: sicionado contra a privatizaçıo Gas empresas publicas e pela in: tervençio no sistema finanoei. ro. 


\title{
C) Histótórica
}

ANNEX III - Supporting text figure 03 - Luiz Inácio Lula da Silva

\author{
Causa Operária e \\ Convergência divergem \\ do partido e têm \\ os dias contados
}

\section{TEREZNHA LOPES}

A Convergencta soclallsta e a Causa Operarla podem estas com seus dias contados dentre do PT. As divergeneteis poblica: eatre o partido e as duan correntea que atuam na legenda da candidato do PT a Presidencia, Luta Indicto Lula da slive, váa exigir providbactas imediatad park conter o desgaste provocado pelas advertencias oontra esoes militantes nos últimos disa e uma posaivel batrs na candidatura petista. "Be continuarem com esea politica, serd incompativel a existescia doa grupos no PT"', admite o secroturio-geral Jose Dirceu.

O presidente do PT, Lulz Gushlken, reconbeceu que "hih um movimento de transereasio As normas internas do partido em agdamento". Casteloso, prometeu apurar ae as atituden partem de atos isotados ou orientaçoes do grupo politico. em oonfronto com as orientacoes do partido. Caso se comprove que hit uma determinagato da cupuln desens oorrentes contira a politica do partido, o próprio Gushiken pediri a instaianuço de uma comisade de etiea park estadar o caso. 


\section{C) HitconTórICA}

Entre outras colsas, a Convergencia e a Causa Operária até hoje relutam em aceitar o nome do senador José Paulo Bisol como candidato a vice na chapa de Lula e tèm uma visâo de politica habitacional contraria a adotada pelo PT. A posstbilidade de essas duas correntes virem a se constituir em partidos políticos nấo fol descartada por Gushiken e Dirceu. Enquanto a Causa Operaria é um grupo minoritário dentro do PT, a Convergéncia Soclalista possui cargos nas instancias dirigentes do partido como, por exemplo, a vice-prefeltura de Diadema ocupada por António Justino, expulso recentemente da legenda. Por conta dos últimos incldentes na prefeitura de Dladema, envolvendo o partido e a Convergéncia, Lula defendeu a ocupaça de terras e teve suas posiçấo endossada por Gushiken. "自 compreensivel trabalhadores invadirem terrenos", afirmou.

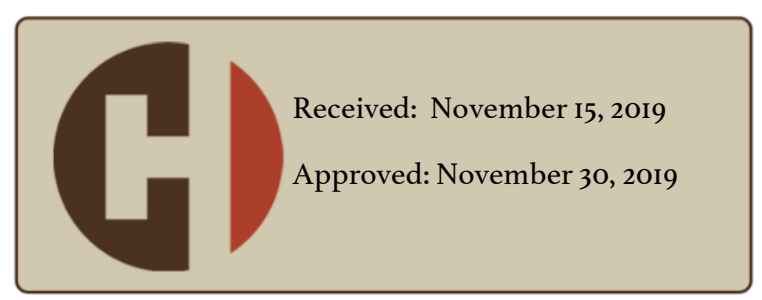

